\title{
Major plant communities of the Marakele National Park
}

\author{
P.J. VAN STADEN and G.J. BREDENKAMP
}

Van Staden, P.J. \& G.J. Bredenkamp. 2005. Major plant communities of the Marakele National Park. Koedoe 48(2): 59-70. Pretoria. ISSN 0075-6458.

To manage and conserve any national park efficiently, a profound knowledge of the ecology is a prerequisite, and to achieve that an inventory of the biotic and abiotic components must be undertaken. As a contribution to such a program this information was collected for Marakele National Park. The study area covers $290.51 \mathrm{~km}^{2}$ in the southwestern part of the Limpopo Province. The underlying parent rock of the study area is sandstone, shale and mudstone with several diabase dykes. The soils range from shallow to deep sandy soils on sandstone and clayey soils on diabase and mudstone. The rainfall varies from $556 \mathrm{~mm}$ to $630 \mathrm{~mm}$ per annum, mainly during the summer months. The study area experiences warm summers with temperatures of up to $32^{\circ} \mathrm{C}$ and cool, dry winters with frost in the low-lying areas. The vegetation of the study area was classified in a hierarchical, plant sociological system by using TWINSPAN and the BraunBlanquet technique. The floristic data from 130 relevés were classified to identify five major plant communities, namely one forest community, three savanna/grassland communities and one wetland community. These plant communities were ecologically interpreted by habitat.The phytosociological table was condensed to a synoptic table to describe the major plant communities.

Key words: Braun-Blanquet, classification, major plant communities, phytosociology, synoptic table.

PJ van Staden, Centre for Wildlife Management, University of Pretoria, 0001 Pretoria; GJ Bredenkamp, Dept of Botany, University of Pretoria, 0001 Pretoria (george.bredenkamp@.up.ac.za)

\section{Introduction}

The primary objective when proclaiming a national park is to conserve parts of pristine natural ecosystems for future generations (Gertenbach 1987). Marakele National Park (MNP) covers an area of $290.51 \mathrm{~km}^{2}$ in the southwestern part of the Limpopo Province and is managed as a national park since 1988, but was officially proclaimed a national park on 11 February 1994.

In order to manage and conserve any conservation area, a profound knowledge of the ecology is a prerequisite, and to achieve that prerequisite, an inventory of the biotic and the abiotic components of that national park must be undertaken (Edwards 1972). The "natural systems" as they occur today cannot be viewed and conserved as "natural" any more, because of the influence of man. Thus, management recommendations can only be made on the basis of interpreted ecological knowledge to restore the balance of the original natural system. The influence of management recommendations on the system must also be regularly monitored to determine if the aims that were set have been achieved satisfactorily. Efficient monitoring systems also depend upon an inventory of the biotic and abiotic components (Gertenbach 1987).

The primary aim of this study was to classify and describe the vegetation of the Marakele National Park in the Waterberg of the Limpopo Province (Van Staden 2003). The purpose of the classification can be described as to form an inventory as a basis of management.

\section{Study area}

The study area covers 29051 ha in the southwestern part of the Limpopo Province of 


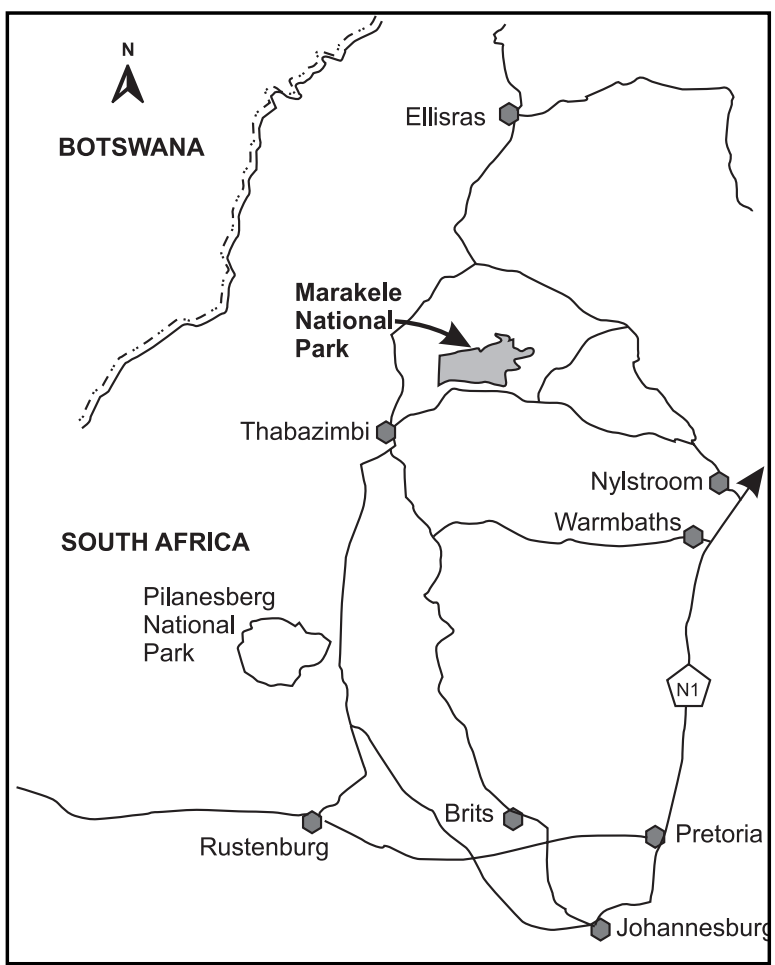

Fig. 1. A map indicating the location of the study area in relation to towns.

South Africa, between $27^{\circ} 30^{\prime} \mathrm{E}-27^{\circ} 45^{\prime} \mathrm{E}$ and $24^{\circ} 15^{\prime}-24^{\circ} 30^{\prime} \mathrm{S}$. The position of the park in relation to towns is shown in Fig. 1 (Van Staden 2003).

The underlying parent rock of the study area (SACS 1980) is sandstone of the Matlabas Subgroup, Aasvoëlkop Formation in the south-western and southern parts; with shale and mudstone of the Matlabas Subgroup, Aasvoëlkop Formation, Groothoek Mudstone Member; a conglomerate outcrop of the Matlabas Subgroup, Aasvoëlkop Formation in the west; and with the biggest part of the study area consisting of sandstone of the Kransberg Subgroup, Sandriviersberg Formation.

The soils that have developed on the parent materials range from shallow to deep sandy soils on sandstone and clayey soils on diabase and mudstone (Van Staden 2003).

The rainfall varies from $556-630 \mathrm{~mm}$ per annum and occurs mainly during the summer months. The study area experiences warm, wet summers with average daily temperatures of $32^{\circ} \mathrm{C}$ and cool, dry winters with frost in the low-lying areas (Van Staden 2003).

MNP is situated mainly in the Waterberg Moist Mountain Bushveld (Low \& Rebelo 1996) in the Savanna Biome (Rutherford \& Westfall 1994). The vegetation of the study area includes Acocks' (1988) Sour Bushveld (Veld Type 20), Mixed Bushveld (Veld Type 18), Sourish Mixed Bushveld (Veld Type 19) and North-Eastern Mountain Sourveld (Veld Type 8). This Sour Bushveld is listed by Edwards (1972) as one of 52 of South 
African Veld Types that is extremely lacking in conservation. The Sour Bushveld covers $18306 \mathrm{~km}^{2}$, occurring in mountainous areas in the previous Transvaal Province (Coetzee 1975; Coetzee et al. 1981). Previous plant ecological studies in the Sour Bushveld (Acocks 1988) include those by Van Vuuren \& Van der Schijff (1970), Coetzee (1975); Coetzee et al. (1981), Westfall (1981) and Westfall et al. 1985. Other plant ecological work of interest in related vegetation types include those of Theron (1973) who described the vegetation of the Loskopdam Nature Reserve; Van der Meulen (1979) who described the vegetation of the bushveld south of the Waterberg; Van Rooyen (1983) who described the vegetation of Roodeplaat Dam Nature Reserve; and Brown (1997) who described the vegetation of Borakalalo Game Reserve.

\section{Methods}

\section{Analysis}

Methods applied are described in detail by Van Staden (2003) and are only summarised here. Stereo aerial photographs on a scale of 1:50 000 (Task 874 of 1984) were used to delineate homogeneous units on the basis of physiography and physiognomy (Bredenkamp \& Theron 1978; Westfall 1981; Gertenbach 1987).

A total of 130 sample plots were surveyed throughout the study area. The sample plot location was determined by means of stratified-random sampling (Westfall 1981). The number of sample plots for each delineated physiographic-physiognomic unit was determined according to the size of each delineated unit.

Termitaria and riparian vegetation was not included in the placing of the sample plots, due to their limited size. Additional sample plots were identified for the termitaria and riparian vegetation and sampling was done in these vegetation types.

A sample plot size of $10 \mathrm{~m} \times 20 \mathrm{~m}$ was fixed and used throughout the study area. This size is considered adequate for surveys in savanna vegetation by Coetzee (1975), Coetzee et al. (1976), Westfall (1981), Van Rooyen (1983) and Gertenbach (1987).

At each sample plot a list of all the species present, was compiled. A cover-abundance value was given to each species according to the Braun-Blanquet cover-abundance scale, as given by Mueller-Dombois \& Ellenberg (1974) and Werger (1974), and adapted by Barkman et al. (1964).

The following habitat information was recorded at each sample plot-symbols are used in the synoptic table: land type was read from the land type map (Land Type Survey Staff 1988); soil forms were classified in accordance with MacVicar et al. (1977); the altitude of each sample plot was recorded using an altimeter and is given in metres; the slope of the terrain of each sample plot was measured in degrees, using an optical clinometer.

The following classification of slope units (Westfall 1981) were used in this study:

\begin{tabular}{lll} 
Symbol & Description & Class \\
\hline $\mathrm{L}$ & level & $0.00^{\circ}-3.49^{\circ}$ \\
$\mathrm{G}$ & gentle & $3.50^{\circ}-17.62^{\circ}$ \\
$\mathrm{M}$ & moderate & $17.63^{\circ}-36.39^{\circ}$ \\
$\mathrm{S}$ & steep & $36.40^{\circ}$ \\
\hline
\end{tabular}

The aspect of the terrain where each sample plot is situated was determined using a compass. Aspect is given in the eight compass directions, namely: $\mathrm{N}$ North; S - South; NE - Northeast; SW - Southwest; E - East; W - West; SE - Southeast; NW - Northwest.

The surface rock cover in each sample plot was estimated as a percentage stones ( $>20 \mathrm{~mm}$ diameter), boulders and rocky outcrops. The following five classes were used, based on its potential influence on mechanical use (ploughing) (Van der Meulen 1979; Westfall 1981):

\begin{tabular}{|c|c|c|}
\hline Symbol & Class & Description \\
\hline $\mathrm{O}$ & $<1 \%$ & $\begin{array}{l}\text { No limitation on } \\
\text { mechanical utilisation }\end{array}$ \\
\hline $\mathrm{L}$ & $1-4 \%$ & $\begin{array}{l}\text { Low limitation on } \\
\text { mechanical utilisation }\end{array}$ \\
\hline M & $5-34 \%$ & $\begin{array}{l}\text { Moderate limitation on } \\
\text { mechanical utilisation }\end{array}$ \\
\hline $\mathrm{H}$ & $35-84 \%$ & $\begin{array}{l}\text { High limitation on } \\
\text { mechanical utilisation }\end{array}$ \\
\hline V & $85-100 \%$ & $\begin{array}{l}\text { No mechanical utilisation } \\
\text { possible }\end{array}$ \\
\hline
\end{tabular}

\section{Synthesis}

The classification is based on the Braun-Blanquet method of vegetation classification, discussed in detail by Westhoff \& Van der Maarel (1980), Mueller-Dombois \& Ellenberg (1974) and Werger (1974). Data were captured on the mainframe computer of the University of Pretoria, in the BBNEW software package. It was then exported to be used in the software package BBPC (Bezuidenhout et al. 
Table 1

Synoptic table of the major plant communities of Marakele National Park

For symbols see text, constancy values $=$ percentage

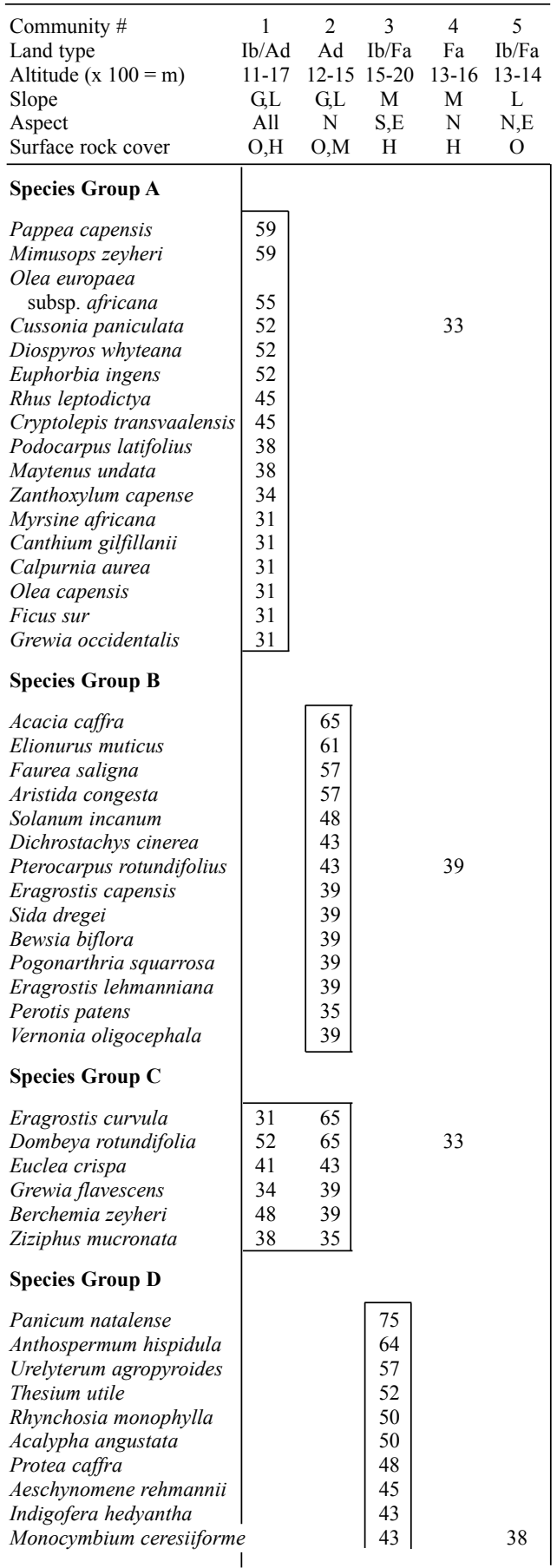

Table 1 (continued)

\begin{tabular}{|c|c|c|c|c|c|}
\hline Community \# & 1 & 2 & 3 & 4 & 5 \\
\hline Land type & $\mathrm{Ib} / \mathrm{Ad}$ & Ad & $\mathrm{Ib} / \mathrm{Fa}$ & $\mathrm{Fa}$ & $\mathrm{Ib} / \mathrm{Fa}$ \\
\hline Altitude $($ x $100=\mathrm{m})$ & $11-17$ & $12-15$ & $15-20$ & $13-16$ & $13-14$ \\
\hline Slope & G,L & $\mathrm{G}, \mathrm{L}$ & M & M & L \\
\hline Aspect & All & $\mathrm{N}$ & $\mathrm{S}, \mathrm{E}$ & $\mathrm{N}$ & $\mathrm{N}, \mathrm{E}$ \\
\hline Surface rock cover & $\mathrm{O}, \mathrm{H}$ & $\mathrm{O}, \mathrm{M}$ & $\mathrm{H}$ & $\mathrm{H}$ & $\mathrm{O}$ \\
\hline Tristachya rehmannii & & & 41 & & \\
\hline Cheilanthus hirta & & & 39 & & \\
\hline Dicoma anomala & & & 39 & & \\
\hline Vernonia galpinii & & & 39 & & \\
\hline Xerophyta retinervus & & & 36 & & \\
\hline Chaetacanthus costatus & & & 36 & & \\
\hline Senecio venosus & & & 36 & & \\
\hline Rhynchosia nitens & & & 34 & & \\
\hline Indigofera mollicoma & & & 34 & & \\
\hline Pentanisia angustifolia & & & 32 & & \\
\hline Parinari capensis & & & 32 & & \\
\hline Species Group E & & & & & \\
\hline Eragrostis racemosa & & 70 & 82 & & \\
\hline Trachypogon spicatus & & 30 & 80 & & \\
\hline Bulbostylis burchellii & & 30 & 73 & & \\
\hline Themeda triandra & & 78 & 59 & & \\
\hline Gnidia capitata & & 43 & 34 & & \\
\hline Species Group F & & & & & \\
\hline Setaria lindenbergiana & & & & 100 & \\
\hline Rhoicissus revoilii & & & & 89 & \\
\hline Hypoestes forskaolii & & & & 78 & \\
\hline Pseudolachnostylis & & & & & \\
\hline maprouneifolia & & & & 78 & \\
\hline Strychnos pungens & & & & 72 & \\
\hline Diplorhynchus & & & & & \\
\hline condylocarpon & & & & 67 & \\
\hline Ochna pulchra & & & & 67 & \\
\hline Elephantorrhiza burkei & & & & 61 & \\
\hline Littonia modesta & & & & 61 & \\
\hline Stylochiton natalense & & & & 56 & \\
\hline Maytenus tenuispina & & & & 56 & \\
\hline Lantana rugosa & & & & 50 & \\
\hline Tephrosia rhodesica & & & & 44 & \\
\hline Cryptolepis oblongifolia & & & & 44 & \\
\hline Tapiphyllum parvifolium & & & & 44 & \\
\hline Kalanchoe paniculata & & & & 39 & \\
\hline Apodytes dimidiata & & & & 39 & \\
\hline Aristida scabrivalvus & & & & 33 & \\
\hline Turraea obtusifolia & & & & 33 & \\
\hline Ancylbotrys capensis & & & & 33 & \\
\hline Talinum caffrum & & & & 33 & \\
\hline Species Group G & & & & & \\
\hline Englerophytum & & & & & \\
\hline magalismontanum & & & 43 & 100 & \\
\hline Aristida transvaalensis & & & 50 & 61 & \\
\hline Rhynchosia totta & & & 52 & 56 & \\
\hline Loudetia simplex & & & 86 & 50 & \\
\hline Tephrosia longipes & & & 68 & 50 & \\
\hline Stachys natalensis & & & 36 & 50 & \\
\hline Sphenostylis angustifolia & & & 45 & 33 & \\
\hline Rhus dentata & & & 45 & 33 & \\
\hline Species Group H & & & & & \\
\hline Burkea africana & & 43 & & 94 & \\
\hline Combretum molle & & 30 & & 94 & \\
\hline Lannea discolor & & 43 & & 83 & \\
\hline Ozoroa paniculosa & & 30 & & 50 & \\
\hline
\end{tabular}


Table 1 (continued)

\begin{tabular}{|c|c|c|c|c|c|}
\hline Community \# & 1 & 2 & 3 & 4 & 5 \\
\hline Land type & $\mathrm{Ib} / \mathrm{Ad}$ & Ad & $\mathrm{Ib} / \mathrm{Fa}$ & $\mathrm{Fa}$ & $\mathrm{Ib} / \mathrm{Fa}$ \\
\hline Altitude $($ x $100=\mathrm{m})$ & $11-17$ & $12-15$ & $15-20$ & $13-16$ & $13-14$ \\
\hline Slope & $\mathrm{G}, \mathrm{L}$ & G,L & M & M & L \\
\hline Aspect & All & $\mathrm{N}$ & $\mathrm{S}, \mathrm{E}$ & $\mathrm{N}$ & $\mathrm{N}, \mathrm{E}$ \\
\hline Surface rock cover & $\mathrm{O}, \mathrm{H}$ & $\mathrm{O}, \mathrm{M}$ & $\mathrm{H}$ & $\mathrm{H}$ & $\mathrm{O}$ \\
\hline Phyllanthus parvulus & & 35 & & 78 & \\
\hline Raphionachne galpinii & & 43 & & 56 & \\
\hline Setaria sphacelata & & 78 & & 44 & \\
\hline Heteropogon contortus & & 87 & & 44 & \\
\hline Vitex rehmannii & & 39 & & 61 & \\
\hline \multicolumn{6}{|l|}{ Species Group I } \\
\hline Andropogon schirensis & & 43 & 80 & 61 & \\
\hline Commelina africana & & 39 & 64 & 100 & \\
\hline Diheteropogon amplectans & & 30 & 73 & 67 & \\
\hline Schizachyrium sanguineum & & 30 & 50 & 33 & \\
\hline Fadogia homblei & & 39 & 57 & 50 & \\
\hline Melinis repens & & 78 & 36 & 72 & \\
\hline Brachiaria serrata & & 70 & 39 & 44 & \\
\hline \multicolumn{6}{|l|}{ Species Group J } \\
\hline Vangueria infausta & 34 & 74 & 55 & 94 & \\
\hline Asparagus transvaalensis & 38 & 39 & 43 & 56 & \\
\hline Pellaea calomelanos & 31 & 30 & 50 & 89 & \\
\hline Cheilanthus viridis & 38 & & & 56 & \\
\hline \multicolumn{6}{|l|}{ Species Group K } \\
\hline Xyris capensis & & & & & 88 \\
\hline Andropogon huilensis & & & & & 88 \\
\hline Miscanthus junceus & & & & & 63 \\
\hline Fuirena pubescens & & & & & 56 \\
\hline Monopsis decipiens & & & & & 50 \\
\hline Helichrysum aureonitens & & & & & 50 \\
\hline Ischaemum fasciculatum & & & & & 44 \\
\hline Aristida junciformis & & & & & 44 \\
\hline Ascolepis capensis & & & & & 44 \\
\hline Sebaea leiostyla & & & & & 44 \\
\hline Hypericum lalandii & & & & & 44 \\
\hline Syzygium cordatum & & & & & 38 \\
\hline Verbena bonariensis & & & & & 38 \\
\hline Cyperus thorncroftii & & & & & 38 \\
\hline Cliffortia linaerifolia & & & & & 31 \\
\hline Arundinella nepalensis & & & & & 31 \\
\hline Drosera madagascariensis & & & & & 31 \\
\hline
\end{tabular}

1996), After a TWINSPAN analysis (Hill 1979), the output of the resulting classification was imported into a spreadsheet, for refinement by Braun-Blanquet procedures (Behr \& Bredenkamp 1988; Bredenkamp \& Brown 2003). The final classification of the relevés was then interpreted for identification of major communities, where-after a synoptic table was compiled by calculating the percentage constancy of each species in each of the major communities identified. The result is given in Table 1 .

\section{Results}

The vegetation composition of the study area is summarised in a synoptic table (Table 1). All species with a constancy value of more than $30 \%$ in any community were included in the synoptic table. This table therefore shows the most frequently found species of each major community and summarises the relationship between the five major plant communities recognised.

\section{Classification}

The following major communities were identified:

A. Forest Communities:

1. Olea europaea subsp. africana -

Diospyros whyteana Major Community

B. Sour Bushveld and North Eastern Mountain Sourveld Communities:

2. Acacia caffra-Heteropogon contortus

Major Community

3. Protea caffra-Loudetia simplex Major Community

4. Burkea africana-Setaria lindenbergiana Major Community

C. Wetland Communities:

\section{Andropogon huilensis-Xyris capensis} Major Community.

\section{Description of the Major Communities}

\section{A Forest Communities}

1. Olea europaea subsp. africana-Diospyros whyteana Major Community

This major community occurs as forests in the kloofs, as dense bush clumps on south and east facing slopes and as bush clumps on termitaria. The kloofs are the least exposed of the geomorphology classes found in the study area, with water in the spruits.

The species composition of the Olea europaea subsp. africana-Diospyros whyteana Major Community is given in Table 1. These forests and dense bush clumps have 
the following diagnostic species, all being trees or shrubs (Species Group A, Table 1): Pappea capensis, Mimusops zeyheri, Olea europaea subsp. africana, Cussonia paniculata, Diospyros whyteana, Euphorbia ingens, Rhus leptodictya, Cryptolepis transvaalensis, Podocarpus latifolius, Maytenus undata, Zanthoxylum capense, Myrsine africana, Canthium gilfillanii, Calpurnia aurea, Ficus sur, Olea capensis and Grewia occidentalis.

Although various different plant communities can be recognised within these forests and bush clumps (Van Staden 2003), species such as Podocarpus latifolius, Mimusops zeyheri, Diospyros whyteana, Canthium gilfillanii and Olea capensis are prominent throughout the range of this vegetation.

Grass and forb species are scanty under the dense forest vegetation, only Eragrostis curvula, Asparagus transvaalensis, Pellaea calomelanos and Cheilanthes viridis occurred with a constancy of more than $30 \%$.

The Olea europaea subsp. africana-Diospyros whyteana Major Community is floristically related to the Sour Bushveld communities (Communities 2, 3 and 4) within the park (Species Group J), but shows particular affinity to the Acacia caffra-Heteropogon contortus Major Community through Species Group C.

Coetzee (1975) described a related community from the Rustenburg Nature Reserve as Hypoestes verticillaris-Mimusops zeyheri Forests, and Westfall (1981) described a similar community from the Farm Groothoek in the Waterberg as Kloof Forest Communities on moderately deep soils in moist, sheltered habitats. Du Preez et al. (1991) classified this type of forest as typical Afromontane Forests, where these forests occur in specific niches in deep valleys, protected gorges, crevices and ravines along the eastern and western slopes of the Drakensberg mountain range.

Coetzee et al. (1976) described termitaria bush clump communities from the Nylsvley Nature Reserve, which have diagnostic species similar to the bush clump communities on termitaria in the Marakele National Park.

B Sour Bushveld and North Eastern Mountain Sourveld Communities

2. Acacia caffra-Heteropogon contortus Major Community

This major community represents a Sour Bushveld (Acocks 1988) with open to dense savanna typically found on the slopes of the Waterberg, and more open woodland or grassland on the summits. This open to closed woodland vegetation is found on gradual to moderately steep slopes (mainly footslopes) of outcrops, hills, ridges and mountains, which are widely distributed over Marakele National Park. It is restricted to shallow and rocky soils with a relatively high nutritional status (Coetzee 1975), derived from diabase and also from quartzite (Bezuidenhout et al. 1994). Many of the sample plots were located on diabase, which forms the substrate of this major community.

On the lower, less rocky slopes with deeper soils the Acacia caffra-dominated vegetation often grades into communities of the plains forming a mixed thornveld, as also described from the Rustenburg Nature Reserve (Coetzee 1975). On the other hand, the most mesic Acacia caffra-dominated vegetation shows some affinity to higher altitude Protea caffra-dominated vegetation that normally occurs at cooler sites (Species Group E, Table 1), at altitudes above the Acacia caffra-dominated vegetation, as also reported by Coetzee (1975).

The soils are mainly shallow, of the Mispah or Glenrosa Form, though deeper soils of the Hutton or Clovelly Form are encountered at the foot of the mountain slopes (MacVicar et al. 1977). The soil depth varies from $100 \mathrm{~mm}$ to more than $1000 \mathrm{~mm}$ (Land Type Survey Staff 1988).

The species composition of the Acacia caffra-Heteropogon contortus Major Community is given in Table 1. This major community is differentiated from the other major communities in the area by the following 
diagnostic plant species (Species Group B, Table 1): Acacia caffra, Faurea saligna, Dichrostachys cinerea, Pterocarpus rotundifolius, Elionurus muticus, Aristida congesta, Eragrostis capensis, Bewsia biflora, Perotis patens, Eragrostis lehmanniana, Pogonarthria squarrosa, Solanum incanum, Sida dregei and Vernonia oligocephala.

Acacia caffra is mostly a dominant woody species, with other prominent species such as Faurea saligna, Burkea africana, Dichrostachys cinerea, Pterocarpus rotundifolius, Vitex rehmannii, Vangueria infausta, Ozoroa paniculosa, Lannea discolor and Combretum molle also prominently present in certain plant communities. Quite often the woody species are grouped in bush clumps, resulting in a savanna with scattered individual trees and bush clumps.

The prominent grass species include Trachypogon spicatus, Themeda triandra, Setaria sphacelata, Schizachyrium sanguineum, Melinis repens, Heteropogon contortus, Eragrostis racemosa, Diheteropogon amplectens, Brachiaria serrata, Andropogon schirensis and the diagnostic Elionurus muticus and Eragrostis lehmanniana.

The most frequently found forbs include Pellaea calomelanos, Gnidia capitata, Fadogia homblei, Bulbostylis burchellii, Asparagus transvaalensis, Solanum incanum and Vernonia oligocephala.

The Sour Bushveld (Acocks 1988) communities that occur in the park (Communities 2, 3 and 4) are all floristically related, indicated by Species Group I, but also through Species Groups E, G and H.

Descriptions of Acacia caffra-dominated vegetation are given by Bezuidenhout et al. (1988) from the Vredefort Dome area, Bezuidenhout \& Bredenkamp (1991) from the North-West Province grasslands and Grobler et al. (2002) from the JohannesburgPretoria area. Particularly good examples (Eustachys mutica-Acacia caffra Woodlands) are provided by Coetzee (1975) from the Rustenburg Nature Reserve, Bezuidenhout et al. (1994) from the slopes of the hills and ridges in the North-West Province, and Coetzee et al. (1994, 1995) from the Magaliesberg in the Pretoria area. Coetzee (1974) described Acacia caffra Savannas on diabase and in sheltered valleys from the Jack Scott Nature Reserve. Westfall (1981) described a similar community as Woodland on moderately deep soils in moderately exposed habitats, from the Farm Groothoek in the Waterberg.

3. Protea caffra-Loudetia simplex Major Community

The Protea caffra-Loudetia simplex Major Community is representative of Acocks' (1988) Sour Bushveld on moderately deep to deep soils in moderately exposed habitats. This mountain bushveld is found on gradual to steep rocky hills and ridges in the Marakele National Park. This vegetation type is prominent on the higher altitude slopes and crests. The soils are mainly very shallow, of the Mispah and Glenrosa Forms. The soil depth varies from $10 \mathrm{~mm}$ to $500 \mathrm{~mm}$ (Land Type Survey Staff 1988).

The species composition of the Protea caffra-Loudetia simplex Major Community is given in Table 1. This major community is differentiated by the following diagnostic plant species (species group D, Table 1):

Protea caffra, Urelyterum agropyroides, Tristachya rehmannii, Panicum natalense, Monocymbium ceresiiforme, Xerophyta retinervus, Vernonia galpinii, Thesium utile, Senecio venosus, Rhynchosia nitens, Rhynchosia monophylla, Pentanisia angustifolia, Parinari capensis, Indigofera mollicoma, Indigofera hedyantha, Dicoma anomala, Cheilanthus hirta, Chaetacanthus costatus, Anthospermum hispidula, Aeschynomene rehmannii and Acalypha angustata.

This major community is dominated by the tree Protea caffra. Other prominent woody species include Vangueria infausta, Rhus dentata and Englerophytum magalismontanum.

The most prominent grasses that are often found in this major community are Trachy- 
pogon spicatus, Themeda triandra, Schizachyrium sanguineum, Melinis repens, Loudetia simplex, Eragrostis racemosa, Diheteropogon amplectens, Brachiaria serrata, Aristida transvaalensis and Andropogon schirensis.

Many forb species are present in this vegetation; the most frequently encountered include Tephrosia longipes, Stachys natalensis, Sphenostylis angustifolia, Rhynchosia totta, Pellaea calomelanos, Gnidia capitata, Fadogia homblei, Commelina africana, Bulbostylis burchellii and Asparagus transvaalensis.

Many authors described Protea caffra-dominated vegetation, mainly from Sour Bushveld and Bankenveld, including Coetzee $(1974,1975)$ from the Magaliesberg area, Bredenkamp \& Theron (1978) from the Suikerbosrand, Behr \& Bredenkamp (1988), from the Witwatersrand, Bezuidenhout et al. (1994) from the Gatsrand area in North-West Province, Coetzee et al. (1995), Bredenkamp \& Brown (1998a; 1998b) from the natural areas of the Western Metropolitan Local Council and Grobler et al. (2002) within various natural open spaces in Gauteng. This emphasises the floristic relationships between Bankenveld, Sour Bushveld and the Drakensberg area (Bredenkamp \& Brown 2003).

\section{Burkea africana-Setaria lindenbergiana Major Community}

This major community represents Sour Bushveld (Acocks 1988). It occurs on gentle to moderately steep slopes of rocky sandstone hills, where soils are litholitic and large rock boulders cover $53 \%$ of the soil surface. Aspects are mostly northerly, and these slopes are warm and dry. The soils are mainly of the Mispah and Glenrosa Forms. The soil varies from $10 \mathrm{~mm}$ to more than $500 \mathrm{~mm}$ in depth (Land Type Survey Staff 1988).

This vegetation type is also found at the northernmost areas of the Bankenveld in the Pretoria and Rustenburg areas and is found at high altitudes on warm northern and northeastern aspects with gradual to very steep slopes (Bredenkamp \& Brown 2003). The shallow soils are covered with large boulders and smaller rocks that in some cases provide moister microhabitats than the surrounding areas.

The species composition of the Burkea africana-Setaria lindenbergiana Major Community is given in Table 1 . This major community is differentiated by the following diagnostic plant species (species group D, Table 1):

Tapiphyllum parvifolium, Strychnos pungens, Rhoicissus revoilii, Pseudolachnostylis maprouneifolia, Ochna pulchra, Maytenus tenuispina, Elephantorrhiza burkei, Diplorhynchus condylocarpon, Cryptolepis oblongifolia, Apodytes dimidiata, Acylobotrys capensis, Setaria lindenbergiana, Aristida scabrivalvus, Turraea obtusifolia, Tephrosia rhodesica, Talinum caffrum, Stylochiton natalense, Littonia modesta, Lantana rugosa, Kalanchoe paniculata and Hypoestes forskaolii.

Apart from the above prominent diagnostic species, other prominent woody species include Vitex rehmannii, Vangueria infausta, Rhus dentata, Ozoroa paniculosa, Lannea discolor, Englerophytum magalismontanum, Combretum molle and Burkea africana.

Grass species that are prominent in this community include Setaria sphacelata, Schizachyrium sanguineum, Melinis repens, Loudetia simplex, Heteropogon contortus, Diheteropogon amplectens, Brachiaria serrata, Aristida transvaalensis and Andropogon schirensis.

Forbs include Tephrosia longipes, Stachys natalensis, Sphenostylis angustifolia, Rhynchosia totta, Pellaea calomelanos, Fadogia homblei, Cheilanthus viridis and Asparagus transvaalensis.

Coetzee (1975) described a similar community as the Barleria bremekampiiDiplorhynchus Tree Savanna from Rustenburg Nature Reserve, and Westfall (1981) described a similar community as a Woodland, representative of Acocks' (1988) Sour 
Bushveld, on moderately deep to deep soils in moderately exposed habitats from the Waterberg.

Further examples of this vegetation were described from the scarps and slopes of the Jack Scott (Coetzee 1974), from the warm temperate mountain bushveld within the Pretoria-Witbank-Heidelberg areas by (Coetzee et al. 1993), from the Melville koppies Nature Reserve (Ellery 1994), from the natural areas of the western local Metropolitan Council of Gauteng by Bredenkamp \& Brown (1998a) and within various natural open spaces in Gauteng by Grobler et al. (2002).

5. Andropogon huilensis-Xyris capensis Major Community Major

Many streams arise in seepage areas, for instance on mountain slopes within Marakele National Park. These are seasonally or perennially waterlogged sponges, with vegetation dominated by sedges and other hygrophilous angiosperms and mosses (Noble \& Hemens 1978). This major wetland community occurs along streams and tributaries of the Matlabas, Mamba and Sterkstroom rivers and shallow submerged marshy areas or sponges.

The soils are wet, mainly of the Avalon, Hutton, Katspruit, Oakleaf and Westleigh Forms, derived from sandstone of the Sandriviersberg Formation (De Vries 1968, 1969). The soil depth varies between 300-1 $200 \mathrm{~mm}$ (Land Type Survey Staff 1988).

The species composition of this wetland Major Community is given in Table 1. This major community is differentiated by the following diagnostic plant species (Species Group K): Syzygium cordatum, Cliffortia linaerifolia, Andropogon huilensis, Aristida junciformis, Arundinella nepalensis, Ischaemum fasciculatum, Miscanthus junceus, Ascolepis capensis, Cyperus thorncroftii, Drosera madagascariensis, Fuirena pubescens, Helichrysum aureonitens, Hypericum lalandii, Monopsis decipiens, Sebaea leiostyla, Verbena bonariensis and Xyris capensis.

Coetzee (1975) described similar communities from the Rustenberg Nature Reserve as the Aristida junciformis-Arundinella nepalensis Grassland and the Pteridium aquilinum-Phragmites mauritianus Reedswamp.

\section{Discussion}

The vegetation of the study area was classified in a hierarchical, plant sociological system by using the Braun- Blanquet technique. The floristic data from 130 relevés were classified to identify five major plant communities. These plant communities were ecologically interpreted by habitats. These major plant communities should form the basis for a management plan, and should also be the basis for a more detailed classification of the vegetation of this national park.

According to White (1978) the majority of the tree species in South African Afromontane forests are widespread. Amongst them are, inter alia, Podocarpus latifolius, Olea capensis and Myrsine africana that occur as diagnostic species in the Olea europaea subsp. africana-Diospyros whyteana Major Community within the study area. These forests on the Waterberg have a clear floristic affinity to the Afromontane forests found in the Drakensberg (Du Preez et al. 1991), indicating a much more widespread distribution of forests at previous times, with the Waterberg forests being a western relict (Bredenkamp et al. 2002). The above mentioned assemblage of species could almost be used to define the Afromontane region as a whole. Not one species occurs throughout, but most species of the assemblage are present on virtually every "island" of Afromontane forest in the region.

It is interesting to note that the vegetation on the termitaria have species similar to the forest communities, and are therefore included into this major community. The greater water holding capacity of the soils worked over by the termites renders these habitats suitable for forest development (Coetzee et al. 1976). 
The Acacia caffra-Heteropogon contortus Major Community on footslopes, Protea caffra-Loudetia simplex Major Community on cooler southerly facing slopes and the Burkea africana-Setaria lindenbergiana Major Community on the warmer northerly facing slopes have a clear floristic relationship with similar plant communities in the Bankenveld. The relationships between Sour Bushveld, Sourish Mixed Bushveld and Bankenveld woodland communities (Acocks 1988) are clearly indicated by Bredenkamp \& Brown (2003) and can further be demonstrated from studies by Van Vuuren \& Van der Schijff (1970), Du Plessis (1972), Theron (1973), Coetzee (1975), Van der Meulen (1979), Westfall (1981) and Coetzee (1993). Furthermore, Coetzee (1993), O’Connor \& Bredenkamp (1997) and Bredenkamp \& Brown (2003) indicated that the Bankenveld vegetation also shows an affinity to the Drakensberg flora. This relationship may also be seen in the presence of the Afromontane forests in the Drakensberg, Bankenveld and Waterberg.

In the cooler, southern parts of the Bankenveld, Acacia caffra-dominated vegetation is usually found on lower and warmer northfacing slopes, e.g., in the Vredefort Dome area, though in the warmer northern parts e.g. the Marakele National Park, it may be found at higher altitudes, on crests or southfacing slopes (Coetzee 1975; Bezuidenhout et al. 1994; Coetzee et al. 1995).

Due to the complex mosaic distribution pattern of the sub-communities that are included under the major communities, a vegetation map is more appropriate when the details of the sub-communities are published.

\section{References}

Acocks, J.P.H. 1988. Veld types of South Africa. Memoirs of the botanical Survey of South Africa 57: 1-146.

Barkman, J.J., J. Moravec \& S. Rauchert. 1964. Kritische Bemerkungen und Vorschläge zur quantitativen Vegetationanalyse. Acta Botanica Neerlandia 13: 394-449.
Behr, C.M. \& G.J. BredenKamp. 1988. A phytosociological classification of the Witwatersrand National Botanical Garden. South African Journal of Botany 54: 525-533.

Bezuidenhout, H. 1992. Verslag oor die abiotiese komponent van die Kransberg Nasionale Park. Unpublished internal report.

Bezuidenhout, H., H.C. BIGGS \& G.J. BREDENKAMP. 1996. A process supported by the utility BBPC for analysing Braun-Blanquet data on a personal computer. Koedoe 39(1): 107-112.

Bezuidenhout, H., \& G.J. BRedenKamp. 1991. The vegetation of the $\mathrm{Bc}$ Land Type in the western Transvaal grassland, South Africa. Phytocoenologia 19: 497-518.

Bezuidenhout, H., G.J. BREdenKamp \& J.H. ElsenBROEK. 1988. Die plantegroei van die alkaligraniet en aangrensende kwartsiet in die Vredefortkoepel noordwes van Parys. SuidAfrikaanse Tydskrif vir Natuurwetenskap en Tegnologie 7: 4-9.

Bezuidenhout, H., G.J. BRedenkamp \& G.K. THERON.1994. Syntaxonomy of the vegetation of the $\mathrm{Fb}$ land type in the western Transvaal grassland, South Africa. South African Journal of Botany 60: 72-80.

BRedenKAmp, G.J. \& L.R. BRown. 1998a. A vegetation assessment of the open spaces in the Western Metropolitan local Council area. Pretoria: Ekotrust CC.

BREDENKAMP, G.J. \& L.R. BRown.1998b. A vegetation assessment of open spaces in the northern areas of the Northern Metropolitan Local Council. Pretoria: Ekotrust CC.

BredenKamp, G.J. \& L.R. BRown. 2003. A reappraisal of Acocks' Bankenveld: Origin and diversity of vegetation types. South African Journal of Botany 69(1): 7-26.

BredenKamp, G.J., F. Spada \& E. Kazmierczak. 2002. On the origin of northern and southern hemisphere grasslands. Plant Ecology 163(2): 209-229.

BredenkAmP, G.J. \& G.K. Theron. 1978. A synecological account of the Suikerbosrand Nature Reserve. 1. The phytosociology of the Witwatersrand geological system. Bothalia 12: 513-529.

BRown, L.R. 1997. A plant ecological study and wildlife management plan of the Borakalalo Nature Reserve, North-west Province. Ph.D. thesis. University of Pretoria, Pretoria.

CoetzeE, B.J. 1974. A phytosociological classification of the vegetation of the Jack Scott Nature Reserve. Bothalia 11: 329 - 347.

Coetzee, B.J. 1975. A phytosociological classification of the Rustenburg Nature Reserve. Bothalia 11: $561-580$.

Coetzee, B.J. \& M.J.A. Werger. 1975. On association-Analysis and the classification of plant communities. Vegetatio 30: 201-206. 
Coetzee, B.J., F. van der Meulen, S. Zwanziger, P. Gonsalves \& P.J. WeIsSER. 1976. A phytosociological classification of the Nylsvley Nature Reserve. Bothalia 12: 137-160.

Coetzee, B.J., P. Van Wyk, W.P.D. Gertenbach, A. Hall-Martin \& S.C.J. JouberT. 1981. 'n Plantekologiese verkenning van die Waterberggebied in die Noord-Transvaalse Bosveld. Koedoe 24:1-23.

Coetzee, J.P. 1993. Phytosociology of the $\mathrm{Ba}$ and $\mathrm{Ib}$ land types in the Pretoria-Witbank-Heidelberg area. MSc thesis, University of Pretoria, Pretoria.

Coetzee, J.P., G.J. Bredenkamp \& N. van Rooyen. 1993. The Sub-humid Warm Temperate Mountain Bushveld plant communities of the PretoriaWitbank-Heidelberg area. South African Journal of Botany 59(6): 623-632.

Coetzee, J.P., G.J. BredenKamp \& N. van Rooyen. 1994. An overview of the physical environment and vegetation units of the $\mathrm{Ba}$ and $\mathrm{Ib}$ land types of the Pretoria-Witbank-Heidelberg area. South African Journal of Botany 60(1): 49-61.

Coetzee, J.P., G.J. Bredenkamp \& N. van Rooyen. 1995. Plant communities of the Sub-humid Cool Temperate Mountain Bushveld in the Pretoria Witbank Heidelberg area. South African Journal of Botany 61: 114-122.

DE VRIES, W.C.P. 1968-69. Stratigraphy of the Waterberg System in the Southern Waterberg area, Northwestern Transvaal. Annals of the geological Survey in South Africa 43-56.

Du Plessis, C.J. 1972. 'n Floristies-ekologiese studie van die plaas Doornkop in die distrik Middelburg, Transvaal. MSc Thesis, University of Pretoria, Pretoria,

Du Preez, P.J., G.J. Bredenkamp \& H.J.T. Venter. 1991. The syntaxonomy and synecology of the forests in the eastern Orange Free State, South Africa. I. The Podocarpetalia latifolii. South African Journal of Botany 57: 198-206.

EDWARDS, D. 1972. Botanical survey and agriculture. Proceedings of the Grassland Society of South Africa 7: 15-19.

ELLERY, W.N. 1994. The vegetation ecology of Melville Koppies Nature reserve and Louw Geldenhuys View Site: Proposals for their Management. Johannesburg: Botanical Society of South Africa.

GERTENBACH, W.P.D. 1987. 'n Ekologiese studie van die Suidelikste Mopanieveld in die Nasionale Krugerwildtuin. D.Sc proefskrif (Ongepubliseer). Universiteit van Pretoria.

Grobler, C.H., G.J. BredenKaM. \& L.R.Brown. 2002. Natural woodland vegetation and plant species richness of the urban open spaces in Gauteng, South Africa. Koedoe 45: 19-34.

HiLl, M.O. 1979. Twinspan - a Fortran program for arranging multivariate data in an ordered two way table by classification of individuals and attributes. Cornell University, Ithaca, New York.

LAND Type Survey StafF. 1988. Land types of the maps 2426 Thabazimbi, 2428 Nylstroom. Memoirs of the agricultural natural Resoures of South Africa 10: 1-431.

Low, A.B. \& A.G. ReBELo. 1996. Vegetation of South Africa, Lesotho and Swaziland. Pretoria: Department of Environmental Affairs and Tourism.

Macvicar, C.N., R.F. Loxton, J.J.N. LAMBrechts, J. LE RouX, J.M. DE Villiers, E. Verster, F.R. MERRY-WeATHER, T.H. VAN ROOYEN \& H.J. VON M. HARMSE. 1977. Grondklassifikasie, 'n binomiese sisteem vir Suid Afrika. Pretoria: Departement Lanbou Tegniese Dienste.

Mueller-Dombois, D. \& H. Ellenberg. 1974. Aims and Methods of Vegetation Ecology. New York: Wiley.

Noble, R.G. \& J. Hemens. 1978. Inland water ecosystems in South Africa a review of research needs. South African Natural Science Progress Report 34: 1-150.

O’Connor, T.G. \& G.J. BredenKamp. 1997. Grassland. Pp. 215-257. In: Cowling R.M., D.M. Richardson \& S.M. PIERCE (eds.). Vegetation of Southern Africa. Cambridge: Cambridge University Press.

Rutherford, M.C. \& R.H. Westfall. 1994. Biomes of southern Africa: An objective categorization. Memoirs of the botanical Survey of South Africa 63: $1-94$

South African COMmission fOR Stratigraphy (SACS). 1980. Statigraphy of South Africa. Part 1 (Comp. L.E. Kent). Lithostratigraphy of the Republic of South Africa, South West Africal Namibie and the Republics of Bophuthatwana, Transkei, and Venda. Pretoria: Government Printer. (Handbook for Geological Survey in South Africa 8.)

ThERON, G.K. 1973. 'n Ekologiese studie van die Plantegroei van die Loskopdam - natuurreservaat Ongepubl. D.Sc - thesis, University of Pretoria, Pretoria.

Van Der Meulen, F. 1979. Plant sociology of the Western Transvaal Bushveld. South Africa: Syntaxonomic and synecological study. Vaduz: Cramer. (Dissertationes Botanica 49.)

VAn Rooyen, N. 1983. Die Plantegroei van die Roodeplaatdam - natuurreservaat II. Die plantgemeenskappe. South African Journal of Botany 2: $115-125$.

Van Staden, P.J. 2002. An ecological study of the plant communities of Marakele National Park. M.Sc. thesis, University of Pretoria, Pretoria.

VAN VuUREN, D.R.J. \& H.P. VAN DER SCHIJFF. 1970. ' $n$ Vergelykende ekologiese studie van die plantegroei van ' $n$ noordelike en suidelike kloof 
van die Magaliesberg. Tydskrif vir Natuurwetenskappe 10: 16-75.

WERGER, M.J.A. 1974. On concepts and techniques applied in the Zürich-Montpellier method of vegetation survey. Bothalia 11(3): 309-323.

WestFall, R.H. 1981. The plant ecology of the farm Groothoek, Thabazimbi District. M.Sc. thesis, University of Pretoria, Pretoria.

Westfall, R.H., N. van RoOyen \& G.K. Theron. 1985. The plant ecology of the farm Groothoek,
Thabazimbi District. 2. Classification. Bothalia 15: 655-688.

Westhoff, V. \& E. Van der MaArel. 1980. The Braun-Blanquet approach. Pp. 287-399. In: R.H. WhitTAKER (ed.). Classification of plant communities. The Hague: Junk.

White, F. 1978. The Afromontane region. Pp. 465513. In: Werger, M.J.A. (ed.). Biogeography and ecology of Southern Africa. The Hague: Junk. 